\title{
Sustainable Redevelopment of Jingxi Abandoned Coal Mine Land: Recreation Spots From Problem Spaces
}

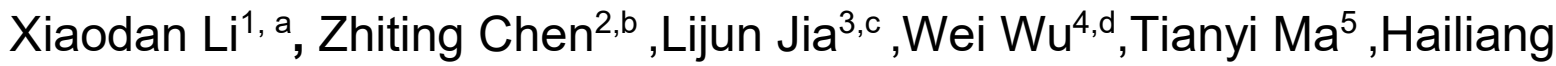 \\ Zhang $^{6}$,Tao Wang ${ }^{7}$ \\ 1,2,3,4,5,6,7 China University of Mining and Technology, Beijing, China
} atjulxd@sina.com, bczt@student.cumtb.edu.cn, ‘654630398@qq.com,,1071750717@qq.com

\begin{abstract}
Keywords: Abandoned coal mine land (ACML), Recreation system, Planning, Redevelopment Abstract. The redevelopment of abandoned coal mine land and the creation of recreation space in cities are two significant elements for fostering urban more sustainable development. This paper presents an systematic perspective on plan strategy making, and examines how Jingxi ACML recreation system may combine with the existing tourism resources in Fangshan District and Mentougou District. Research employed a questionnaire survey and interviewed many residents around Jingxi coalfields. Based on a lot of site-investigations, to solve current problems, it is suggested that Jingxi ACML recreation system should consist of A Major Center, A Sub-center, and Two Axes.
\end{abstract}

\section{Introduction}

As the only state-owned coal mine in Beijing, Jingxi Coal Mine has made an important role in the energy supply in meeting coal demand in Beijing and surrounding cities.[1] And according to Overall Urban Planning of Beijing (2016-2035), Beijing should become the national political center, cultural center, international communication center, and scientific \& technological innovation center in China. Jingxi Coal Mine is located in Mentougou District and Fangshan District, which are eco-conserving divisions and the key areas for the sustainable development of Beijing. Therefore, Jingxi Coal Mine is suggested to transform its current resource-based economy to an ecological economy.[2]

According to international experience, if a country's income per capita exceeds US $\$ 1000$, the recreation needs of its residents will expand rapidly. And the income per capita of US \$2000 will lead to diverse recreational needs. The income per capita of $\$ 3000$ (about RMB18933) will make the residents' demand for recreation more universal[3]. According to Statistical Communique on the National Economy and Social Development of Beijing in 2017, per capita disposable income of urban residents hit RMB 62,406, up by $9.0 \%$, and that of rural residents reached RMB 24,240, up by $8.7 \%$. Therefore, the recreational needs of Beijing residents have been very universal. In addition, based on a sample survey of Beijing residents' recreational aspirations in $2005,99.1 \%$ of them want to visit Beijing subsurbs[4].

In summary, reusing Jingxi ACML as a mining recreation system has great potential both in reality and in theory.[5]

\section{General Situation of Jingxi Coal Mine}

Jingxi Coal Mine is located in the Yanshan Mountains, which have significant value in the world geological history.The coalfield mainly distributes in Mentougou District and Fangshan District. Its 
outer edge extends to Shijingshan District, Fengtai District, Haidian District in Beijing and Laishui County in Hebei. It is $45 \mathrm{~km}$ from east to west and $35 \mathrm{~km}$ from north to south, and covers an area of $1019 \mathrm{~km}^{2}$ in Beijing. Mentougou District has a total area of $1450.7 \mathrm{~km}^{2}$. And its coalfield has a total area of $700 \mathrm{~km}^{2}$, [6] including Wangping Town, Tanzhesi Town, Yongding Town, Longquan Town,

Junzhuang Town, Zhaitang Town, Qingshui Town, Dadai Office and Chengzi Office. There are 8 coal-producing towns (Xiayunling Town, Shijiaying Town, Da'anshan Town, Fozzhuang Town, Nanjiao Town, Hebei Town, Zhoukoudian Town and Puwa Town) in the north of Fangshan District and the upper and middle reaches of the Dashi River.

There are plenty of traditional recreation spots in Fangshan District and Mentougou District, such as Ancient West Peking Path, humanistic landscapes, historical and cultural

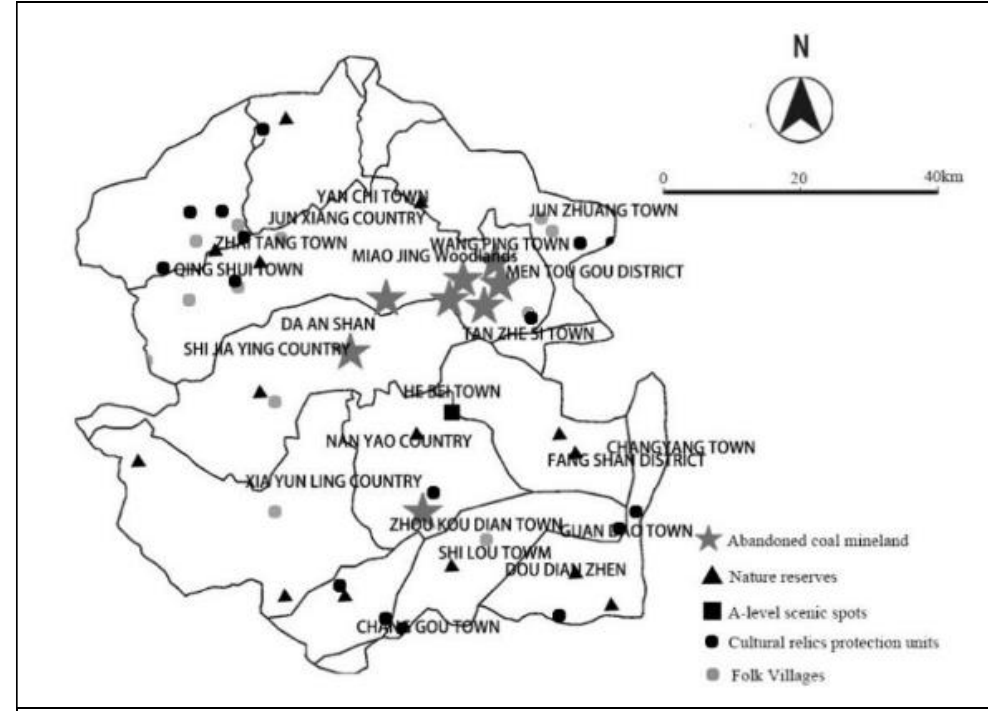

Fig. 1 Distribution of Jingxi ACML ancient villages.( Fig. 1) With dense forests and quiet environment, they have always been hot spots are important ecological conservation areaes in the capital Beijing. [7]In addition, Mentougou District has become the only dual zone demonstration unit in Beijing since 2017, because it is not only a national tourism reform and innovation leading area, but also a national tourism demonstration area.

\section{Historical Evolution of Jingxi Coal Mine}

According to historical records, Jingxi coalfield originated in the Liao and Jin dynasties. Its scale was greatly expanded in Yuan and Ming dynasties. And in the middle of the Qing dynasty, its development reached its climax and became the Royal official Kiln. In the 27th year of Qianlong in Qing Dynasty (1762), there were 273 coal mines in Beijing: 16 coal mines in Xishan, 117 coal mines in Wanping County, and 140 coal mines in Fangshan County.In the 1860s, countries such as Britain, Germany, the US, Italy, Belgium, Japan began to open mines and build coal transportation railways in Beijing. At that time, there were several mines including Tongxing Coal Mine (jointly organized by China and the US), Yumao Coal Mine (jointly managed by China and Belgium), Tianli Coal Mine (jointly managed by China and German), Mentougou Coal Mine (jointly managed by China and Britain), and Yangtuo Coal Mine (jointly organized by China and Japan). At the same time, national capitalistic coal mines were also trying to expand their scales. [8]According to China Coal Mine: in 1935, there were more than 630 national coal kilns in the west of Beijing.

Jingxi Mining Area Management Agency has been an important industrial enterprise providing coal resources for Beijing since 1949. And it also managed the local government's administrative affairs until the establishment of Beijing Mining Bureau. Beijing Mining Bureau was reorganized into Beijing coal group in 2001. In December 2002, Jingxi Mining Group formed Beijing Hanhua Energy Co.Ltd ,under the Jingmei Coal Group.

Beijing Mining Bureau had 10 mines in former years.[1] After 1990s, with the development of market economy and the change of coal market, the exhausted coal mine land like Mentougou Coal Mine, Chengzi Coal Mine, Fangshan Coal Mine, Heitugang Coal Mine, Wang Ping Coal 
Mine(including Anjiatan and Huapogen), and Yangtuo Coal Mine had been shut down successively. The remaining four coal mines were Muchengjian Coal Mine (now known as Muchengjian and Qianjuntai), Dadai Coal Mine, Da'anshan Coal Mine, and Changgouyu Coal Mine. Their annual output is about 5 million tons.

\section{Investigation and Analysis of the present situation of Jingxi Coal Mine}

Status of Jingxi Coal Mine. This paper makes a field investigation on 8 existing mining areas in Jingxi Coal Mine(Table 1). Except that Anjiatan coal mine was not found, the remaining coal mines' industrial facilities have been relatively well-preserved, and their auxiliary industrial plants have great potential for reuse.[5]

Table 1 Survey and Records of Jingxi ACML

\begin{tabular}{|c|c|c|c|c|c|c|}
\hline No. & Name & Location & $\begin{array}{c}\text { Time of } \\
\text { construc } \\
\text { tion }\end{array}$ & $\begin{array}{c}\text { Area } \\
{\left[\mathrm{km}^{2}\right]}\end{array}$ & Status & Recent photo \\
\hline 1 & $\begin{array}{l}\text { Wang } \\
\text { ping } \\
\text { Coal } \\
\text { Mine }\end{array}$ & $\begin{array}{c}\text { Nan Jian } \\
\text { Village, } \\
\text { Wangpin } \\
\mathrm{g} \\
\text { Town,M } \\
\text { entougou } \\
\text { District }\end{array}$ & 1960 & 13.5 & $\begin{array}{c}\text { Closed, } \\
\text { August } \\
2016\end{array}$ & \\
\hline 2 & $\begin{array}{l}\text { Anjiat } \\
\text { an } \\
\text { Coal } \\
\text { Mine }\end{array}$ & $\begin{array}{l}\text { Anjiatan } \\
\text { Village, } \\
\text { Wangpin } \\
\text { g Town }\end{array}$ & 1954 & No data & $\begin{array}{c}\text { Scrapped } \\
, 1960\end{array}$ & data \\
\hline 3 & $\begin{array}{l}\text { Datai } \\
\text { Coal } \\
\text { Mine }\end{array}$ & $\begin{array}{c}\text { Datai } \\
\text { Street ,M } \\
\text { entougou } \\
\text { District }\end{array}$ & $\begin{array}{l}\text { May, } \\
1958\end{array}$ & No data & $\begin{array}{l}\text { Plan to } \\
\text { be } \\
\text { closed } \\
2020\end{array}$ & \\
\hline 4 & $\begin{array}{c}\text { Much } \\
\text { engjia } \\
\text { n Coal } \\
\text { Mine }\end{array}$ & $\begin{array}{c}\text { Qianjunt } \\
\text { ai } \\
\text { Village, } \\
\text { Datai } \\
\text { Street ,M } \\
\text { entougou } \\
\text { District }\end{array}$ & 1954. & No data & $\begin{array}{c}\text { Plan to } \\
\text { be } \\
\text { closed } \\
2019\end{array}$ & \\
\hline
\end{tabular}




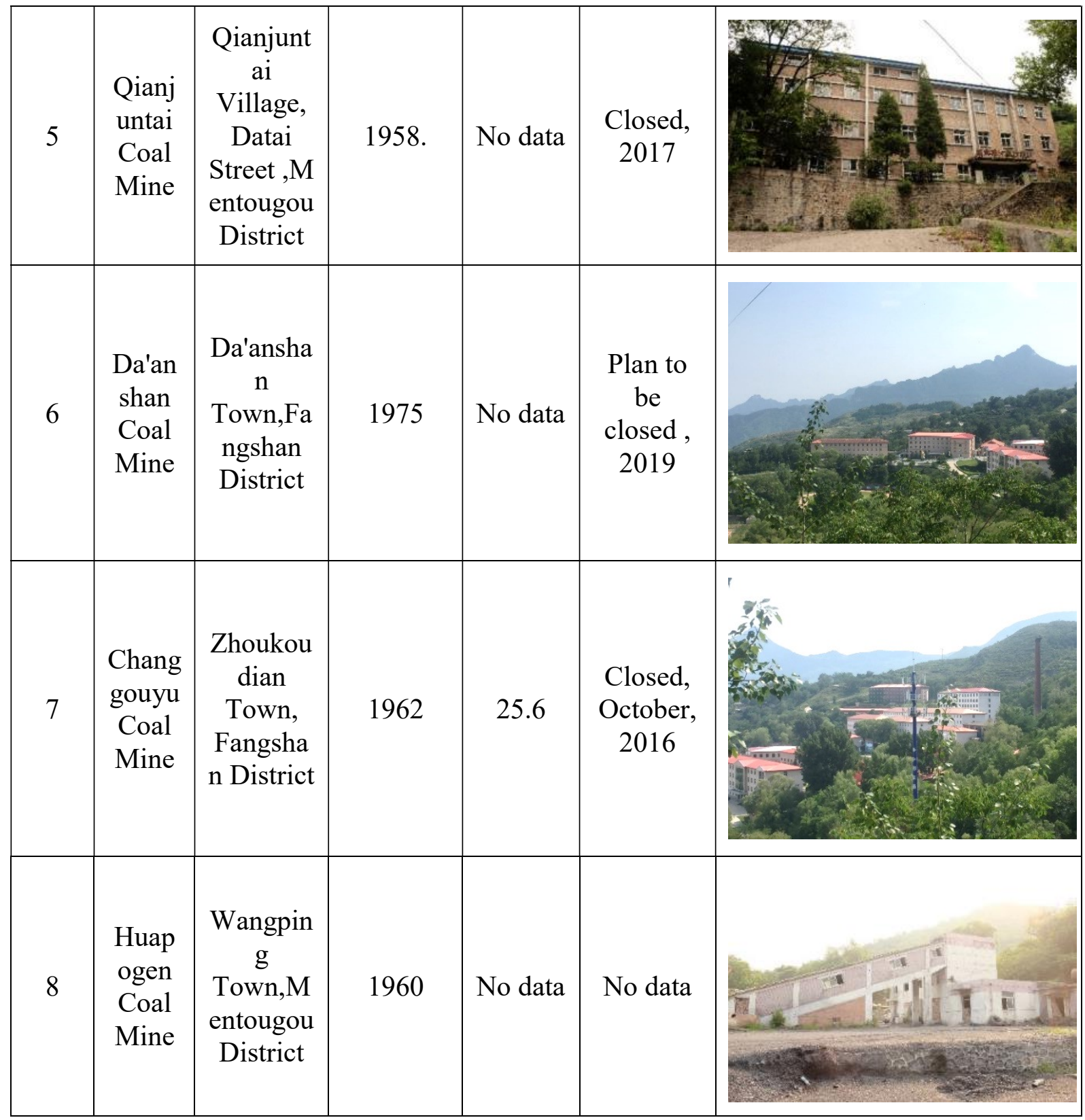

Analysis of Residents' Questionnaire Results. Data for the present study were gathered by means of a survey carried out around 8 coalfields which would be recreational areas. [5]And Field visits were conducted during the summer holiday in 2017, when people prefer living in the suburbs.

A total of 156 questionnaires were distributed, and 143 valid questionnaires were collected. The results are as shown in Table 2:

Table 2 Survey Results of Residents Rround Jingxi ACML

\begin{tabular}{|c|l|l|}
\hline Number & \multicolumn{1}{|c|}{ Questions } & \multicolumn{1}{|c|}{ Results } \\
\hline 1 & $\begin{array}{l}\text { What do you think of the surrounding } \\
\text { environment of Jingxi Coal Mine? } \\
\text { (Single) }\end{array}$ & $\begin{array}{l}\text { A. Good }(47.83 \%) ; \\
\text { B. Excellent }(28.26 \%) ; \\
\text { C. Bad }(23.92 \%)\end{array}$ \\
\hline 2 & $\begin{array}{l}\text { A. Unwilling }(43.48 \%) ; \\
\text { Would you like to work, live or live } \\
\text { around mines? (Single) }\end{array}$ & $\begin{array}{l}\text { B. All are fine }(32.61 \%) ; \\
\text { C. Willing to work rather than live } \\
(19.57 \%) ;\end{array}$ \\
\hline
\end{tabular}




\begin{tabular}{|c|c|c|}
\hline & & D. Willing to live rather than work $(4.35 \%)$ \\
\hline 3 & $\begin{array}{l}\text { What is the impression that the } \\
\text { mining areas bring to you? (Multiple) }\end{array}$ & $\begin{array}{l}\text { A. Their pollution to the environment. } \\
(58.7 \%) \\
\text { B. Their Mining Culture }(52.17 \%) \\
\text { C. Their security concerns. }(43.48 \%) \\
\text { D. They are shabby, affecting the } \\
\text { appearance of Beijing. ( } 23.91 \%) \\
\text { E. They hinder the sustainable growth of } \\
\text { the local economy. }(8.7 \%)\end{array}$ \\
\hline 4 & $\begin{array}{l}\text { Are you in favour of reconstructing } \\
\text { the abandoned mines? (Single) }\end{array}$ & $\begin{array}{l}\text { A. Agree. It can improve local economic } \\
\text { development }(71.74 \%) \\
\text { B. Neutrality. It's none of my business } \\
\quad(28.26 \%) \\
\text { C. Object. It's a waste of money. }(0 \%)\end{array}$ \\
\hline 5 & $\begin{array}{l}\text { Do you think the existing mining } \\
\text { facilities should be retained in } \\
\text { mines? (Single) }\end{array}$ & $\begin{array}{l}\text { A. Optional reservation }(86.96 \%) \\
\text { B. All should be retained. }(8.7 \%) \\
\text { C. All should be removed }(4.35 \%)\end{array}$ \\
\hline 6 & $\begin{array}{l}\text { If there is a chance to go to a mining } \\
\text { area, which of the following factor } \\
\text { may affect you most? (Single) }\end{array}$ & $\begin{array}{l}\text { A. Ecological condition }(30.43 \%) \\
\text { B. Surrounding traffic conditions }(30.43 \%) \\
\text { C. Local cultural characteristics }(23.91 \%) \\
\text { D. Richness of activities }(13.04 \%) \\
\text { E. Shopping environment }(2.17 \%)\end{array}$ \\
\hline 7 & $\begin{array}{l}\text { Which of the following types do you } \\
\text { want ro reuse coalfields } \\
\text { for?[9]( Multiple) }\end{array}$ & $\begin{array}{l}\text { A. Mine park }(54.35 \%) \\
\text { B. Holiday village }(45.65 \%) \\
\text { C. Cultural and creative center }(43.48 \%) \\
\text { D. City of the dead }(28.26 \%) \\
\text { E. Scientific research and training center } \\
\quad(21.74 \%) \\
\text { F. Farmland / woodland }(15.22 \%) \\
\text { G. Department store }(4.35 \%) \\
\text { H. Others }(2.17 \%)\end{array}$ \\
\hline 8 & $\begin{array}{l}\text { What do you think the government } \\
\text { should pay attention to in the process } \\
\text { of reusing mines?[10] (Multiple) }\end{array}$ & $\begin{array}{l}\text { A. Meeting the living needs of the } \\
\text { surrounding residents }(76.09 \%) \\
\text { B. Reducing the impact on the surrounding } \\
\text { environment }(67.39 \%) \\
\text { C. Increasing attention to residents' } \\
\text { recreational needs ( } 45.65 \%) \\
\text { D. Retaining their machinery and industrial } \\
\text { buildings }(30.43 \%)\end{array}$ \\
\hline 9 & $\begin{array}{l}\text { What positive impacts do you think } \\
\text { the reuse of Jingxi mines will bring to } \\
\text { your life?[11] (Multiple) }\end{array}$ & $\begin{array}{l}\text { A. Significantly improving the surrounding } \\
\text { environment }(60.87 \%) \\
\text { B. Driving the development of surrounding } \\
\text { commerce }(58.7 \%) \\
\text { A. Increasing the income of the local } \\
\text { population }(50 \%) \\
\text { B. Protecting mining heritage }(50 \%) \\
\text { C. Making no difference }(2.17 \%) \\
\text { D. Others ( } 0 \%)\end{array}$ \\
\hline 10 & $\begin{array}{l}\text { What negative impacts do you think } \\
\text { the reuse of Jingxi mines will bring to } \\
\text { your life?[12] (Multiple) }\end{array}$ & $\begin{array}{l}\text { A. Worsening the environment }(65.22 \%) \\
\text { B. Noise pollution ( } 43.48 \%) \\
\text { C. Infringement of land requisition, } \\
\text { etc. }(36.96 \%) \\
\text { D. Making no difference }(10.87 \%) \\
\text { E. Others }(0 \%)\end{array}$ \\
\hline
\end{tabular}


Table 2 shows that: local residents think ecological environment around Jingxi ACML is excellent (Question 1,2,3). Most of them are very supportive of the reuse of Jingxi ACML(Question 4). They hope that, on the premise of optimizing the environment and selectively retaining mining and metallurgical facilities, Jingxi ACML should be reused as recreation facilities such as mine parks, resorts and cultural and creative centers(Question5,6,7,8,9,10).

\section{Discussion on the Feasibility Plan of Recreational Planning for Jingxi ACML}

Implementing the Development Strategy of Jingxi ACML Recreation System. Besides Changgouyu Coal Mine, the remaining 7 coal mines are closely distributed around Xishan in Beijing. Therefore, from the perspective of urban planning, Jingxi ACML should be regarded as a whole to be redeveloped.[13] This paper suggests that the Development Strategy of Jingxi ACML Recreation System can be implemented. It can revitalize millennia-long coal mine culture and cultural landscapes in Beijing. This strategy needs some means such as systematic management and physical reform, etc. It has integrated the ecological restoration, industrial transformation and recreation planning of Jingxi ACML, which will improve the richness of Beijing suburban recreation systems.

Taking Planning Strategy-- a major center, a sub-center, and two axes. According to the survey of leisure tourism market in Beijing suburbs in 2013, the top three categories of recreational projects are leisure vacation, ecological environment and cultural relics.The development of Jingxi ACML recreation system is based on the close connection with the streamline of the original scenic spot and to satisfy the residents' desire for recreation.

According to the regional topography and traffic situation of Jingxi coal mine, it is suggested to adopt the planning strategy of a recreation system-- a major center, a sub-center, and two axes : Wang Ping ACML is in the town of Wang Ping, which is a must-have for Mentougou downtown and other mining areas. So it was planned as the major center and originator of the entire mining recreation system. Based on the existing traffic line, Qianjuntai ACML is at the junction of Jingxi coal mining system and the original scenic recreation system. So it is planned as the "sub-center" and "middle station" of the entire system. The north axis connects the existing traditional recreation routes. And the southern axis connects 7 coal mines. (As shown in Fig. 2)

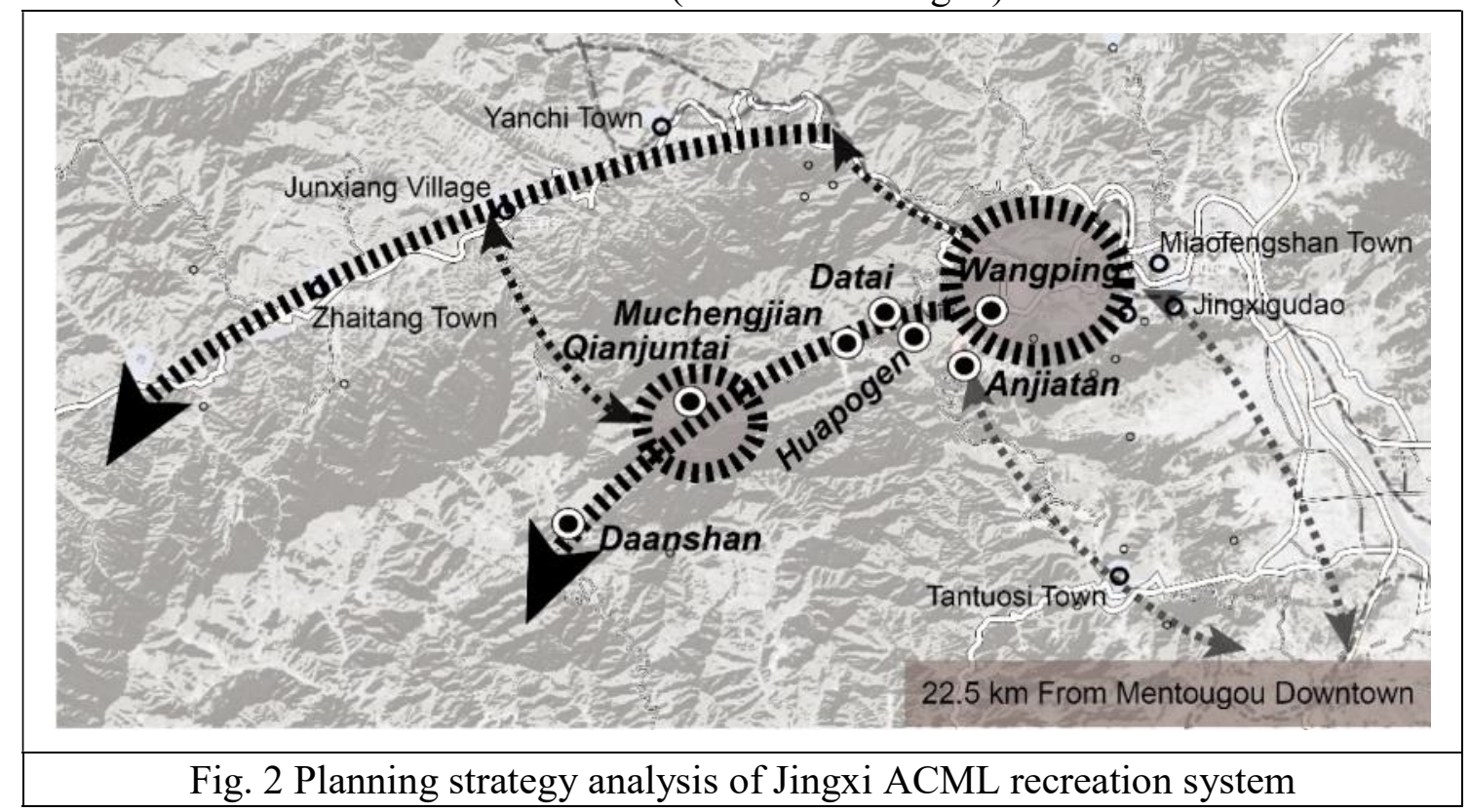

Jingxi ACML Recreation System's Function Structure and Layout. According to Fig. 1, there are only traditional humanities and natural landscapes in the existing recreation system of Mentougou 
and Fangshan District. They lack mining recreation landscapes which reflect the coal mining and metallurgical culture in Beijing. Jingxi ACML recreation system consists of the following 7 function areas. (As shown in Fig. 3)

Wang Ping ACML--Tourist Reception Center. Wangping ACML not only has a superior geographical location, but also has well-preserved construction facilities. So it is the best place in all mining areas to be served as a reception center.

Huapogen ACML--Cultural and Creative Park. This center combines nostalgic industrial culture with fashion art. It is a functional park that integrates production, shopping, entertainment and cultural edification. It is beneficial to build a special souvenir and mascot of Jingxi coal mine culture, and it enhances the competitiveness and attraction of Jingxi coal mine culture.

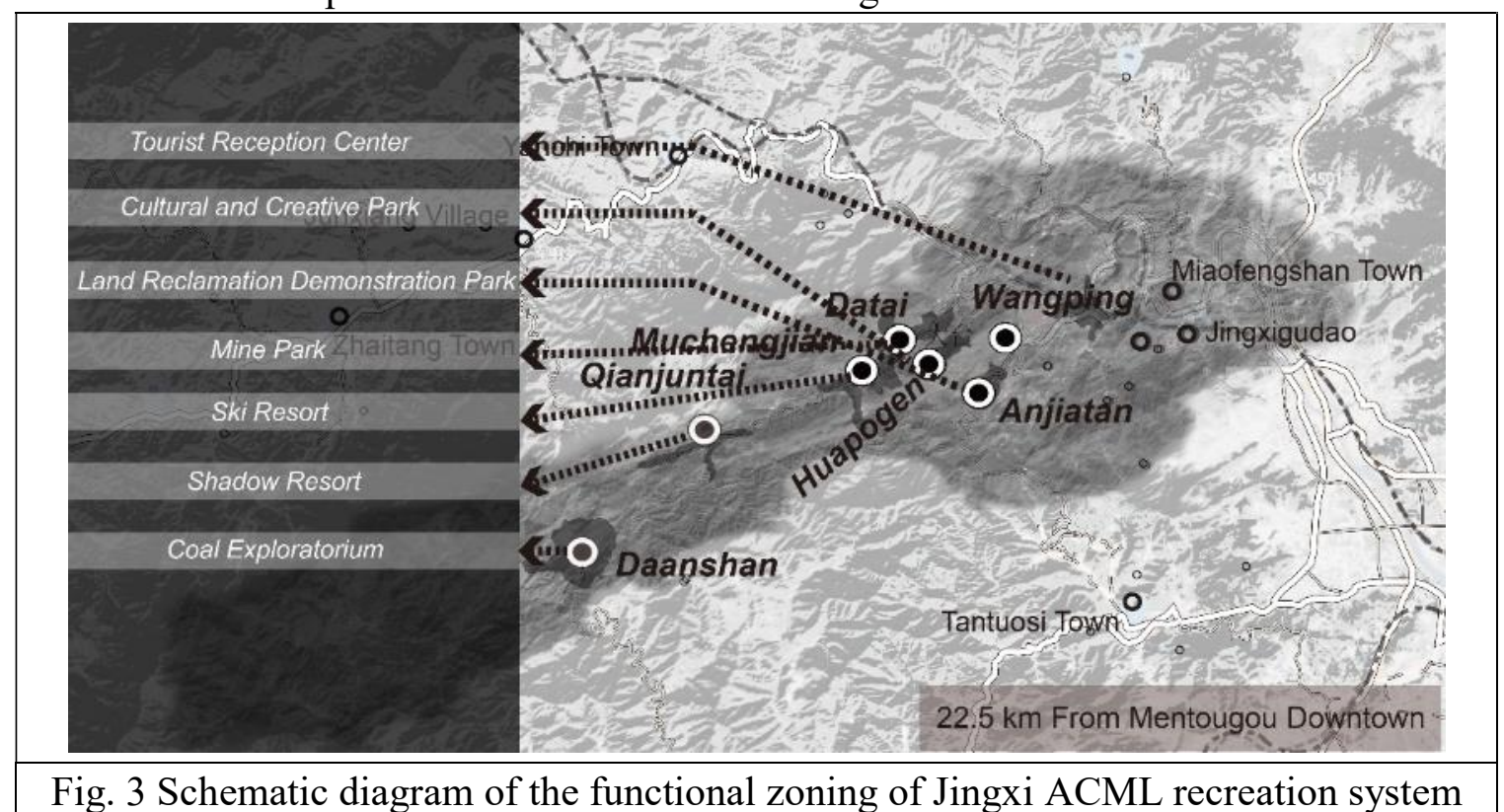

Anjiatan ACML-- Land Reclamation Demonstration Park. Reclamation has always been one of the national hot spots in the field of ecological restoration. Land that has been reclaimed before in Anjiatan is the foundation of the establishment of its future ecological demonstration park.It can be used as the popular science garden and typical demonstration base of ecological restoration technology and facilities.

Datai ACML--Mine Park. Datai ACML is located in the residential area of Datai Subdistrict Office. Its industrial facilities are well-preserved, and their layout is very centralized. Therefore, the planning of Datai ACML as the Jingxi Mining Park will not only help the urban tourists to experience the essence of Jingxi coal mine culture in a short time, but also satisfy the local residents' recreational needs.

Muchengjian ACML--Ski Resort. Muchengjian coal mine is backed by the border zone between Mentougou and Fangshan mountain area. Its terrain is ideal for being designed as a ski resort. And its ground and underground tracks can be used as ski area transportation systems.

Qianjuntai ACML - Shadow Resort. Qianjuntai Village, where Qianjuntai ACML is located, is not only a rare summer resort for Beijing, but also a traditional village with millennium culture. The integration of mining culture and ancient village culture is conducive to their common prosperity and development.

Da'anshan ACML--Coal Exploratorium. Da'anshan coal mine was built according to the mountains. It is suitable for being transformed into an expedition coal mine museum. 


\section{Conclusion}

With the general trend of urban ecological environment and the extensive increase of residents' recreation demand, it is an inevitable trend for ACML to be reused for recreation area. This paper aims at the problem of the reuse of "Royal Coal Mine" Jingxi ACML, which existed more than one thousand years. It makes a beneficial exploration for the planning transformation of the traditional ACML.

In addition, there has always been such a difficult problem: government and enterprises, which should be responsible for the reuse of ACML. This paper regards Jingxi ACML as a whole system to be redeveloped. Jingxi ACML recreation system is not only beneficial to the management of coal mining enterprises, but also more conducive to the inheritance of Beijing for thousands of years of coal mining culture.

\section{Acknowledgements}

Thanks to Beijing Coal Group for providing a lot of information for this study. I would also like to thank my project assistants Lijun Jia and Wei WU,the anonymous reviewers and the Editor.

\section{References}

[1] Shusen Yuan: Coal in old Beijing.( Academy Press. Beijing 2005).

[2] Cole, D., Exploring the Sustainability of Mining Heritage Tourism. 2004. 12(6): p. 480 - 494.

[3] Xiaodan Li, Sijia Sun, Daqian Zhao, Zhiting Chen. Tourists'Demands for Construction of Scenic and Recreational Forests in Beijing Mountainous Area. Chinese Landscape Architecture,2013 (09):101-105.

[4] Shuang Qi,Hua Fu.The investigation on the present situation of Beijing's leisure vacation travel in suburbs. Journal of Capital normal University (Natural Science Edition),2013,34(02):74-78.

[5] De Sousa, C.A., Unearthing the benefits of brownfield to green space projects: An examination of project use and quality of life impacts. 2006. 11(5): 577 - 600.

[6] Bai, Y., R. Wang and J. Jin, Water eco-service assessment and compensation in a coal mining region - A case study in the Mentougou District in Beijing. Ecological Complexity, 2011. 8(2): p. 144-152.

[7] Suili Xiao, Liming Jia, Ping Wang, Construction of Recreation Opportunity Spectrum in Suburban Mountain Region of Beijing. Progress in Geography, 2011 (6): 746-752.

[8] Huihua Lu. Ancient and Modern Coal Mining in Beijing. 16th Symposium of the Geological History Research Association of the Chinese Geological Society.2009:7-12.

[9] SCHMITZ, M.F., I. DE ARANZABAL and F.D. PINEDA, Spatial analysis of visitor preferences in the outdoor recreational niche of Mediterranean cultural landscapes. Environmental Conservation, 2007. 34(04).

[10] Matsuoka, R.H. and R. Kaplan, People needs in the urban landscape: Analysis of Landscape And Urban Planning contributions. Landscape and Urban Planning, 2008. 84(1): p. 7-19.

[11] Heberle, L. and K. Wernstedt, Understanding brownfields regeneration in the US. 2006. 11(5): p. 479 - 497.

[12] Zhang, L. and D.B. Klenosky, Residents' perceptions and attitudes toward waste treatment facility sites and their possible conversion: A literature review. Urban Forestry \& Urban Greening, 2016. 20: p. 32-42. 
[13] Gobster, P.H., Perception and use of a metropolitan greenway system for recreation. 1995. 33(1): p. $401-413$. 